[Letter]

\title{
Selective Hydrogenation of Phenylacetylene with Graphite Intercalated Platinum Nanosheets
}

\author{
Masayuki Shirai $^{\dagger 1) *}$, Bhalchandra M. Bhanage ${ }^{\dagger 2)}$, Hisanori Senboku ${ }^{\dagger 2)}$, Shin-ichiro Fujita ${ }^{\dagger 2)}$, \\ and Masahiko Arai ${ }^{\dagger 2}$, \\ ${ }^{\dagger 1}$ Supercritical Fluid Research Center, National Institute of Advanced Industrial Science and Technology, \\ Nigatake, Miyagino, Sendai 983-8551, JAPAN \\ ${ }^{\dagger 2}$ Div. of Materials Engineering and Chemistry, Graduate School of Engineering, Hokkaido University, \\ Sapporo 060-8628, JAPAN
}

(Received August 5, 2002)

Platinum nanosheets between graphite layers were active for hydrogenation of ethynyl group of phenylacetylene but less active for that of aromatic rings of phenylacetylene and benzene due to its structural characteristics.

\section{Keywords}

Platinum catalyst, Graphite intercalated compound, Phenylacethylene, Selective hydrogenation

Platinum(IV) chloride can be intercalated into a graphite (Lonza KS6) in a chlorine atmosphere ${ }^{1,2)}$. It is interesting to see from transmission electron microscopy that subsequent hydrogen reduction causes the formation of two-dimensional platinum nanosheets with a thickness of 2-3 nm between graphite layers. The platinum nanosheets have a number of hexagonal holes and edge angles of $120^{\circ}$ induced by the interaction between platinum species and graphite layers. The structure of the platinum species of the graphite intercalated compound is expected to have a different catalytic action due to its characteristic structure, as compared with conventional supported platinum catalysts. The present work has been undertaken to examine this expectation, selective catalysis, using hydrogenation of phenylacetylene, which is industrially and scientifically interesting ${ }^{3}$.

The detailed procedures for the preparation of our Pt-GIC samples are described elsewhere ${ }^{1,2)}$. In addition to Pt-GIC, two conventional supported catalysts were used for comparison, which were $\mathrm{Pt}$ on alumina and activated carbon $\left(\mathrm{Pt}_{\mathrm{A}} \mathrm{Al}_{2} \mathrm{O}_{3}\right.$ and $\mathrm{Pt} / \mathrm{C}$, Wako Pure Chemical Ind., Ltd.). The state of Pt dispersion was examined by hydrogen adsorption at room temperaure. Hydrogen was not adsorbed on Pt-GIC. The dispersions for $\mathrm{Pt} / \mathrm{Al}_{2} \mathrm{O}_{3}$ and $\mathrm{Pt} / \mathrm{C}$ were 0.2 and 0.1 , respectively. Fine sphere particles with a size of $3 \mathrm{~nm}$ and a narrow distribution were observed in the TEM images of $5 \mathrm{wt} \% \mathrm{Pt} / \mathrm{Al}_{2} \mathrm{O}_{3}$ sample. Spherical platinum particles were also observed in $5 \mathrm{wt} \% \mathrm{Pt} / \mathrm{C}$ sample; however, the range of particle size distribution was wide $(2-100 \mathrm{~nm})$. The $\mathrm{Pt}$ particle size distribution is very different between the two conventional catalysts.

The hydrogenation reactions were conducted in a batch reactor and the reaction products were analyzed by gas chromatograph and mass spectroscopy. The results obtained are given in Table 1. For hydrogenation of phenylacetylene, all the catalysts gave $100 \%$ conversion, producing a major product, ethylbenzene, with a minor product, ethylcyclohexane. The rate of hydrogenation of the ethynyl group is faster than that of the aromatic ring.

\footnotetext{
“黒鉛層間白金ナノシート触媒によるフェニルアセチレンの選択的水素化反応”

白井誠之 ${ }^{\dagger 1) *}$, B.M.Bhanage ${ }^{\dagger 2)}$ ，仙北久典 ${ }^{\dagger 2)}$ ，藤田進一郎 ${ }^{\dagger 2)}$ ，荒井正彦 ${ }^{\dagger 2}$

${ }^{+1}$ 産業技術総合研究所 超臨界流体研究センタ一，983-8551 仙台市宮城野区苦竹 4-2-1

†2)北海道大学大学院工学研究科, 060-8628 札幌市北区北 13 条西 8 丁目

*連絡先, E-mail: m.shirai@aist.go.jp
} 
The selectivity values were similar for both conventional platinum supported catalysts, having different $\mathrm{Pt}$ dispersion, and so this hydrogenation is structure insensitive. It is worth noting that the quantity of ethylcyclohexane formed with Pt-GIC is smaller by more than one order of magnitude compared with those with the supported Pt catalysts under the same conditions used. When the reaction was continued with Pt-GIC for $15 \mathrm{~h}$, the quantity of ethylcyclohexane increased while that of ethylbenzene slightly decreased, indicating that only a small fraction of ethylbenzene formed was further hydrogenated to ethylcyclohexane. For hydrogenation of benzene only cyclohexane was formed but there was a marked difference in the conversion between Pt-GIC and Pt/C. Namely, the Pt-GIC catalyst is much less active for the hydrogenation of benzene. Table 1 demonstrates a significant result that the aromatic rings are difficult to hydrogenate with Pt-GIC compared with the conventional supported $\mathrm{Pt}$ particles. The ethynyl group of phenylacetylene is hydrogenated with Pt-GIC, and so the two substrates, phenylacetylene and benzene, can get access to active sites of platinum nanosheets between graphite layers. However, the space between the graphite layers is limited and the periphery of the $\mathrm{Pt}$ nanosheets should be active sites; hence the aromatic ring may be adsorbed in a mode of mono- or di- $\sigma$ adsorption while the adsorption with the $\pi$ ring parallel to the Pt surface is unlikely to occur. We also speculate that the attack of hydrogen to the aromatic rings is limited from the side of them due to the characteristic structure of Pt-GIC and they are difficult to be hydrogenated through such a side attack of hydrogen. In contrast, such effects are unlikely to appear with the carbon-carbon triple bonds. In addition, we should consider the difference in the nature of exposed Pt nanosheets and supported threedimensional Pt particles.

The Pt-GIC material would be an interesting catalyst for selective hydrogenation of substituted aromatic compounds, which can hydrogenate aliphatic unsaturated bonds with leaving the aromatic rings unchanged.

Table 1 Activity and Selectivity in Hydrogenation of Phenylacetylene and Benzene for Pt-GIC and Conventional Supported Pt Catalysts

\begin{tabular}{lcccc}
\hline \multirow{2}{*}{ Catalysts } & Time $[\mathrm{h}]$ & Conversion [\%] & \multicolumn{2}{c}{ Products formed [mmol] } \\
\cline { 5 - 5 } & & & Ethylbenzene & Ethylcycohexane \\
\hline (a) Phenylacetylene at $313 \mathrm{~K}$ & & 100 & 8.74 & 0.26 \\
$5.0 \mathrm{wt} \% \mathrm{Pt} / \mathrm{Al}_{2} \mathrm{O}_{3}$ & 15 & 100 & 8.62 & 0.38 \\
& 3 & 100 & 8.55 & 0.45 \\
$5.0 \mathrm{wt} \% \mathrm{Pt} / \mathrm{C}$ & 15 & 100 & 8.36 & 0.64 \\
& 3 & 100 & 8.97 & 0.027 \\
$6.3 \mathrm{wt} \% \mathrm{Pt}-\mathrm{GIC}$ & 15 & 100 & 8.90 & 0.10 \\
\hline (b) Benzene at $323 \mathrm{~K}$ & 3 & 32.8 & & \\
$5.0 \mathrm{wt} \% \mathrm{Pt} / \mathrm{C}$ & 15 & 41.9 & & \\
& 3 & 0.4 & & \\
$6.3 \mathrm{wt} \% \mathrm{Pt}-\mathrm{GIC}$ & 15 & 2.4 & & \\
\end{tabular}

Substrate: phenylacetylene $9.0 \mathrm{mmol}$, benzene $9.0 \mathrm{mmol}$. Catalyst: $\mathrm{Pt} / \mathrm{Al}_{2} \mathrm{O}_{3}, \mathrm{Pt} / \mathrm{C} 50 \mathrm{mg}$, Pt-GIC, $38 \mathrm{mg}$ (The same amount of platinum was used). $\mathrm{H}_{2}: 4.0 \mathrm{MPa}$. Solvent: ethanol $4 \mathrm{~cm}^{3}$.

\section{References}

1) Shirai, M., Igeta, K., Arai, M., Chem. Commun., 2000, 623.

2) Shirai, M., Igeta, K., Arai, M., J. Phys. Chem. B, 105, 7211 (2001).

3) Vergunst, T., Kapteijn, F., Moulijin, J., Ind. Eng. Chem. Res., 40, 2801 (2001). 